\title{
On Currency Power
}

\author{
Xuefeng $\mathrm{Hu}$ \\ Kexin Geotechnical Engineering Investigation, Jiangsu Branch Co., Ltd., Xuzhou 221006, China
}

Tel: 86-516-8218-7931Ｅ-mail: huxefeng666@126.com

Meng Guan

Xuzhou Branch, Construction Bank of China, Xuzhou 221000, China

E-mail:jssincere@163.com

\begin{abstract}
In this paper, the in-depth study of currency concept comes to the conclusion that currency is quantified right and currency has the attribute of power. On this basis, this paper has made some brief analysis of social phenomena and put forward new views on social economic development.
\end{abstract}

Keywords: Commodity, Currency, Power, Right

\section{Introduction}

More facts indicate that modern economic system has deficiencies and shortcomings, which has also shaken the scientific of modern economic theory. And this shortcoming is not only reflected in the matured theoretical system, it is probable that the basis of this system is imperfect itself. This paper seeks to start from the most basic monetary theory and tries to find some clues. Through studies, the author finds that currency is only a quantitative unit of social right in nature. It has the attribute of power and is different from the "wealth" or "equivalent".

\section{Modern monetary theory's shortcomings in explaining the currency}

In summary, although there are many differences in modern financial theory's understandings to currency, especially to its definition, which is more various, their recognition to the origin of currency is basically the same. They regard the exchange of commodities as the research base for currency, agreeing that currency originated from differentiated products, with a measure of value, payment, storage, and other functions.

Therefore, whether people's recognition to currency is correct or not is based on people's understandings to commodities and the exchange of commodities.

So, we really understand the commodities, or that our understandings of commodities and the management are correct and appropriate? What is on earth the commodity? How is it come? It seems to have not a problem. It is well known that commodities are products of labor for exchange. Since currency can be used to exchange the products of labors, then what currency is seems to be clear. Currency is also a kind of product of labor. It is an equivalent, used for equivalent exchange for products of labors. But if the thing in exchange is a product of labor in itself, "currency is the product of labor" is correct. And if the thing in exchange is not a product, we can not simply conclude that "currency is a product of labor".

In fact, the so-called exchange has a precondition: the two parties should have the ownership of products in exchange, that is, people's right of disposing of products and right to use are derived from the ownership. If a person has no ownership to products, the exchange of products is meaningless, or even illegal. So people exchange, first on the job should be to the exchange of such ownership, rather than the product itself. Therefore, currency should be equivalent with ownership but not product itself. People carry out the commodity exchange is the process of quantitative ownership (monetization). In this way, to take currency simply as product in understanding and management is flawed.

\section{Currency is a right unit and has an attribute of power.}

To understand the true nature of currency, we should start with from the exchange of commodities.

\subsection{The nature of exchange of commodities}

In fact, what we tend to discuss the purpose of commodity exchange is the "exchange of ownership". The exchange of commodities is essentially the exchange of ownership. For example, the buying and selling real estate does not require that the seller gives the real estate to the buyer directly. They merely exchange currency with the "deed", "leases", and other things to prove ownership. Therefore, the nature of commodity exchange is 
the exchange of ownership, rather then the product itself.

\subsection{Ownership is from the society}

Prior to the formation of the private system, due to low productivity, and material deprivation, the distribution of social products of labors is mainly primitive public ownership. The purpose of production and labor is self-sufficiency. With increased productivity, products have a surplus. The exchange has also been necessary. On this basis, private goods receive social recognition and licensing. Items were given ownership. The exchange was to take place. Such "private" is a social given, which first of all is a social "right".

Ownership of commodities needs recognition and maintenance of other social members. Exchange of commodities requires to be guaranteed by social order. Thus, ownership is given by the society. It is the social attribute of commodity and also the social attribute of property.

\subsection{The history of monetary development shows that currency is ownership}

From original barter to current currency exchange, commodity exchange is in fact in the exchange of ownership. "Currency commodity" is the carrier of ownership at the very beginning. It seems that currency and commodity are inseparable, and there is no difference between them. However, with the historical development of currency, currency gradually divests its use value. It only represents ownership, namely today's notes, or more advanced forms.

At the historical stage, two parties' items in the transaction serve as both commodities and currency. Currency is not separated from commodities. At this stage, the ownership and the products are the one. The ownership of one commodity is represented and measured by another commodity's quantity and weight. As a result, people may mistake the exchange of products as exchanging products, which has nothing to do with social rights.

With the development of productivity, and the acceleration of circulation, we need a thing that is widely accepted by social members, with low value in use, not easily to be consumed, measureable, and storable to replace a party in exchange, in order to increase the circulation convenience and speed. Therefore, people gradually focus on gold, silver and other metals. Then, gold and silver become relatively rare. People with gold and silver are increasingly available in the market for more things. People think gold and silver are precious because they can get more and more things in exchange. Their prices become higher and higher. Till the whole society recognize the value of gold and silver, the ownership of all commodities is measured by the weight of gold and silver. Gold and silver in a period of time naturally become currency (the main function of gold and silver is the same with modern currency anti-counterfeiting technology).

Whether that is to say gold and silver in people's daily life are more and more valuable in use? Obviously not. It can equate the real estate bubble. It high prices are resulted from social members reserving it. It is reasonable that gold and silver are not valuable or rare as they enter the exchange field at the very beginning. At least, everyone should possess some and not a luxury. In practice, gold and silver are useless in daily life. In sense they have no value in use. In nature, its supply does not match up with its economic volume. It can be understood: at the gold and silver-based period, if they are not used for exchanges, their value would be practically zero. Because of its small volume and it can be replaced by other metals in use. Nobody uses it as an appliance of life. What it represents is only a unit measuring social credit. Social ownership is measured by gold and silver, that is, the unit of ownership at that time is "ounce". If there was today's advanced and exclusive technology (anti-counterfeit paper money), gold and silver can be replaced completely. There is no need to through the metal currency phase. And gold and silver in modern society would not be "reserved". Gold and silver may be not so "precious". Further, whether can we replace the few remaining value of note?

Gold and silver monetary system collapsed many times in history, what are resulted from people's large "reserve". Metal currency can not increase the quantity according to trading volume, on the country would be saved. And the vast majority of people will exchange more goods with a small part of currency through "counteroffer". It reflects the unequal position of currency and common commodities from one side. In this way, after a period of time it will cause the deflation. Gold and silver will gradually withdraw from the market. The market will face recession. People live hard. It may depend on some illegal means to solve a series of issues. Make gold and silver back to the market. In history, it causes a number of regime change and turbulence. In fact, it is the economic crisis. These negative consequences are generated by the metallic monetary system, and also the inherent flaws. Without a clear understanding of it, this situation will continue. Gold and silver monetary system collapsed many times in history, which illustrates that, from another point of view, gold and silver can act as currency as its supply matches up with economic aggregate during certain period. At other time, to take gold and silver as currency is inappropriate. It is the same reason if we take shellfish, cloth, stone (jade), etc. as 
currency.

At the coins and notes time, the currency's attribute of power is also very clear. "Bad money drives out good money" and now the notes in use precisely explain that currency does not require valuable in itself, just to have a stable credit representative. It is only an expression of ownership. Because we can adjust the volume of notes according to the circulation to stabilize the value of currency, it maintains the stability of modern political and social credit.

Therefore, currency is the representative of ownership. It is a right. Currency is a quantitative unit of ownership.

\subsection{The currency has the attribute of power}

Because currency can exchange with any other commodity, its position differs from other commodities in exchange. It is paramount. Therefore, people's purpose of production gradually changes from self- sufficiency to actualizing the value of labor through exchange of products, achieving social recognition, and obtaining more ownership. It is what we call "earn money". Social products are inseparable from human labor. Payment forms an objective recognition, promotion, request, and order of social labor. So, currency has the attribute of power. In other words, currency payment is tantamount to the exercise of power. The distribution of currency is equal to decentralization. The accumulation of currency is equivalent to centralization, while seeking for market monopoly is equivalent to dictatorship.

\subsection{The requirements of currency power for currency management}

Since the ownership is conferred by the society, to acquire the right and to exercise the right should be in accordance with social law. Otherwise, it will violate the public interests. If there is no supervision over it, it will be unthinkable.

In traditional currency theory, currency has no attributes of society and power. Only people have power. Therefore, social supervision only targets on people who associated with currency. As a result, it will invade individuals' other rights. So the resistance is very huge. The supervision effect can imagine.

According to the currency power theory, since currency is power, it is reasonable that social supervision is only for currency. This requires that currency should not be anonymous but should be marked with name. For each circulation ring, two trading parties and public management are indispensable.

\section{Mistakes in traditional currency management}

The main mistake in traditional currency theory is to overlook the commodities' attribute of power (society), blocking people clear understanding of the currency. It will inevitably equate currency management with the management of labor products. Under the guidance of "free trade", banks are enterprises. They do not possess the function of managing powers. To give the management of power to market and free competition, an invisible hand, is to produce a possibility of social abuse of power. Social administration and management has been weakened. The recognition to market and the supervision have been restricted. A lot of problems can not be solved. In fact, a market with absolute freedom, without social management guidance, has limited management capacity. There is not much difference from the primitive society. Too much emphasis on freedom will lead to the "anarchic" state. And this "market economy" management is often the "morning after". Although it can be adjusted, the economy has been deeply hurt.

\subsection{Cash}

In daily life the "cash" is a must under the influences of the view "currency is commodity". If this concept does not change, the cash will live for a long time. Now the cash used by us is actually a "bearer of rights". And the rights, lacking of social supervision, is the root caused illegal transaction. In order to stop illegal transaction, the gradual elimination of cash is the only way to go. Cash should be replaced by money marked with name. By this way, the circulation of currency will be supervised and controlled. But it does not necessary be "no cash". It should be "cash with name". It needs convenient banking system as the support.

\subsection{Banks}

Banks are the main financial service institutions today. Under the traditional currency theory system, banks are institutions that help people management "property". They belong to enterprises and have no attribute of management. To acquire profits is the purpose of enterprises. For the sake of acquiring profits, all banks set up outlets as few as possible. And inter-bank payments will be limited due to certain "fee". People's accounts are not unique. In this case, use of money marketed with name is impossible to realize. However, in the currency power theory, banks are the institutions managing social ownership, but not enterprises. They should be a part of public management and possess the function of supervision. 


\subsection{Illegal transaction}

Considering the requirements for creating a fair, just, healthy, orderly, and modern social development environment, many transactions are forbidden strictly. These transactions are illegal transactions. Since traditional currency theory can not avoid the existence of "cash", illegal transactions can achieve the same convenience with legal transactions. Illegal transactions are even more convenient than legal transactions because they escape from supervision and taxation, such as workplace corruption, smuggling, drug trafficking, tax evasion, buying stolen goods, selling stolen goods, illegal operations, and road occupation. In order to eliminate these illegal transactions, the government needs to establish a large regulatory body to maintain social order, so that the social management falls into this paradox: firstly provide a convenient tool for crime, and then use a large amount of management resources to eliminate it; in order to enforce strict discipline, public administration agencies also have to punish "corrupt" public servants seriously (it is unfair to give all responsibility to the government). All these activities may cause the rise of social management cost, but the efficiency can not be improved greatly. Meanwhile, it also makes people who take risks in illegal transactions to be sacrificed. The use of currency with name will exert a deterrent effect on illegal transactions to a great degree, increasing the difficulty of illegal transactions, and making the acquirement of evidence of illegal transactions easier.

\subsection{Financial crisis}

Financial crisis is triggered by credit crisis in nature, which closely associates with the over development of virtual economy and the obstruction (default) of currency circulation, what is also the main performance of weak credit supervision and regulation. Credit regulation should be also an important task of financial management. Under the traditional currency theory, it is impossible for deep supervision and regulation.

\subsection{Socialism and capitalism}

The main differences between socialism and capitalism are manifested in all its forms: one takes the public ownership as the mainstay, the other takes the private ownership as the mainstay; one is dominated by planned adjustment, the other is dominated by market adjustment. Socialism uses plans to manage the market and emphasizes on powers. Capitalism uses the market to manage plans and emphasizes on capitals. In perspective of currency power theory, there is no essential distinction between the two.

Firstly, because currency is power, the management system in capitalism is to emphasize the full delegation of authority, while the socialism emphasizes on moderate authoritarian. The two kinds of authorities have different expressions. Capitalism brings about reform and efficiency to the society at the very beginning, but too much decentralization will lead to anarchy. Socialism emphasizes on moderate authoritarian, but it has a high requirement for government decision.

Secondly, the development of capitalism and socialism is ultimately the same. Capitalism advocates social management to the market and currency. The ideal must be "rule by doing nothing". The ultimate goal of socialism is communism, and the social management to the people's consciousness, is actually a kind of inaction. These two social systems have higher requirements for social development ultimately.

Socialism is the most appropriate social system that is for productivity development. Adequate allocation of resources through market decentralization, and the government's management makes the social development "smart".

If socialist society can achieve scientific management on authorities and market further, it is achievable for the communist ideal. After all, it is not difficulty to remove the anonymous currency, which, perhaps, should be Marx's demise of monetary.

\section{The feasibility of the implementation of currency power theory}

The main requirement of currency power theory is to abolish the anonymous currency and take the currency with name. Considering the scientific and technological level and costs, it can be achieved.

First of all, the use of cash is decreasing today. And now the non-cash transactions are also very convenient, which is supported by relevant technologies. In theory, to abolish anonymous cash is not difficult.

Secondly, there are many repetitive arrangements, overlapping business, and duplicate work in the existing banking and social financial management system, which objectively results in an increasing circulation rings, larger resistance in currency circulation, and poor circulation. If we achieve the full integration of these resources, it will not increase the transaction costs and management costs on one hand, on the other hand, but may be reduced. The third payment platform appeared in electronic commerce in real society has already played this role. 
It should be an extension of banks' functions.

Thirdly, after canceling the anonymous currency, it eliminates banks' "running" risks. "Deposits" turn into bank management's social right. It is not necessary for banks attracting deposits. Then, the market would have the capability of resisting larger financial risks.

\section{Conclusion}

Currency theory is the basic theory of economic theories. A clear understanding of currency makes economic life more orderly and harmonious, make social choice more appropriate for self development, benefiting social legislation construction, further integrating ideology, and speeding up socialism construction. Although difficult to implement, to be sure, but after all, we can have a specific goal.

In short, to change the currency view would have a great social reform. Because of author's limited abilities, deficiencies are inevitable in this paper. The author is waiting for experts and scholars' criticism, corrections, and perfect. In writing this paper, the author gets a lot of help and suggestions from many friends. Here, thanks from the bottom.

\section{Reference}

Adam Smith. (2007). An Inquiry into the Nature and Causes of the Wealth on Nations. Beijing: New World Press.

Keynes. (2007). The General Theory of Employment, Interest and Money. Beijing: Jiuzhou Press.

Keynes. (2008). A Treatise On Money. Xi'an: Shaanxi Normal University Press.

Fan, Miaojiang \& Liu, Xin. (2006). Development and Reconstruction of Monetary Theory. Beijing: Renmin Publishing House.

Gao, Hongye. (2000). Western Economics. Beijing: China Renmin University Press.

Huang, Da. (2005). Finance. Beijing: China Renmin University Press.

Hu, Yijian. (2008). For Taxation Course. Shanghai: Gezhi Press.

Liu, Bingying. (2007). Capital Selected Readings and Brief Discussion. Beijing: Huaxia Publishing House.

Liu, Xin. Guo, Jinxing \& Wang, Cailing. (2006). Capital Theory and Monetary Theory. Beijing: Renmin Publishing House.

Song, Hongbing. (2007). Currency War. Beijing: China Citic Press.

Zhu, Min. (2009). The Financial Crisis that Changes the Future. Beijing: China Financial Publishing House. 